\title{
PENERAPAN COOPERATIVE LEARNING DENGAN STRATEGI BERMAIN JAWABAN DALAM MENINGKATKAN HASIL BELAJAR BIOLOGI MATERI STRUKTUR DAN FUNGSI SEL PADA SISTEM REPRODUKSI DI KELAS XI
}

\author{
Erlina
}

\author{
MAN 4 Pidie
}

\begin{abstract}
ABSTRAK
Tujuan penelitian ini adalah untuk mengetahui penerapan cooperative learning dengan strategi bermain jawaban dapat meningkatkan hasil belajar biologi materi struktur dan fungsi sel pada sistem reproduksi di Kelas XI IPA.1 MAN 4 Pidie Kabupaten Pidie Tahun Pelajaran 2016/2017. Penelitian ini merupakan penelitian tindakan kelas, yang terdiri 2 siklus, dimana masing-masing siklus terdiri dari perencanaan, pelaksanaan, observasi dan refleksi. Yang menjadi subjek penelitian ini adalah siswa-siswi MAN 4 Pidie Kabupaten Pidie yang berjumlah 31 siswa. Sedangkan yang menjadi objek penelitian adalah Hasil belajar mata pelajaran biologi di kelas XI IPA.1 melalui penerapan cooperative learning dengan strategi bermain jawaban. Hasil penelitian menunjukkan bahwa (1) bahwa penggunaan cooperative learning dengan strategi bermain jawaban dapat meningkatkan hasil belajar siswa pada konsep struktur dan fungsi sel pada sistem reproduksi di Kelas XI IPA.1 MAN 4 Pidie, diaman pada siklus I, siswa yang memperoleh nilai tuntas KKM 75 sebanyak 19 siswa dengan persentase $61 \%$ dan meningkat pada siklus II menjadi 26 orang dengan persentase 84\%; dan (2) penggunaan cooperative learning dengan strategi bermain jawaban dapat meningkatkan aktivitas siswa pada konsep struktur dan fungsi sel pada sistem reproduksi di Kelas XI IPA.1 MAN 4 Pidie, dimana aktifitas siswa pada siklus I sebanyak $64 \%$ siswa aktif dalam kegiatan PBM dan setelah dilakukan perbaikan dalam PBM pada siklus II terjadi peningkatan aktivitas siswa menjadi 71,86.
\end{abstract}

Kata Kunci:Cooperative Learning Dengan Strategi Bermain Jawaban Dan Biologi

\section{PENDAHULUAN}

Proses kegiatan belajar mengajar merupakan rangkaian kegiatan komunikasi antara siswa dengan guru. Proses belajar mengajar dikatakan efektif apabila terjadi transfer belajar yaitu materi pelajaran yang disajikan guru dapat diserap kedalam struktur kognitif siswa. Siswa dapat mengetahui materi tersebut tidak hanya terbatas pada tahap ingatan saja tatapi bahan pelajaran tersebut dapat diserap secara bermakana (meaning learning)serta dapat mengkonstruksi pengetahuan baru dalam pikirannya untuk memecahkan masalah.

Belajar merupakan aktivitas yang dilakukan seseorang atau peserta didik secara pribadi dan sepihak. Agar memperoleh hasil yang maksimal dan optimal, maka dalam proses belajar mengajar guru harus mempunyai metode atau model pembelajaran yang menyenangkan agar siswa tidak merasa bosan terhadap suasanan kelas serta apa yang diajarkan oleh guru. Dalam proses pendidikan di sekolah kegiatan pembelajaran memegang peranan yang sangat penting. Berhasil atau tidaknya tujuan pembelajaran tergantung pada proses kegiatan pembelajaran yang dilakukan guru di kelas. Kegiatan pembelajaran akan dianggap bermutu tinggi apabila proses pembelajaran yang dilaksanakan benarbenar efektif bagi pencapaian kemampuan, keterampilan dan sikap peserta didik.

Menurut Isjoni (2009:11) mengatakan bahwa guru juga memiliki peran yang sanagat penting dalam menentukan kualitas dan kuantitas pengajaran yang dilaksanakannya. Oleh sebab itu, guru harus memikirkan dan membuat perencanaan 
secara seksama dalam meningkatakan kesempatan belajar bagi peserta didiknya dan memperbaiki kualitas mengajaranya. Hal ini menuntut perubahan-perubahan dalam suatu pengorganisasian kelas, penggunaan metode mengajar, strategi belajar-mengajar, maupun sikap dan karakteristik guru dalam mengelola prosesbelajarmengajar.Menurut

Suryosubroto(2009:61) menjelaskan bahwa proses belajar mengajar hendaknya selalu mengikuti peserta didik secara aktif guna mengembangkan kemampuan-kemampuan peserta didik, antara lain kemampuan mengamati,menginterprestasikan,

meramalkan,mengaplikasikan konsep, merencanakan dan melaksanakan penelitian, serta mengkomunikasikan hasil penemuannya. Dalam proses pembelajaran guru mempunyai tugas untuk memilih model pembelajaran beserta media yang tepat sesuai dengan materi yang disampaikan demi tercapainya tujuan pembelajaran. Agar terjadi transfer belajar yang efektif maka diperlukan adanya interaksi yang harmonis antara guru dan peserta didik ataupun dengan sesama peserta didik dalam proses balajar mengajar khususnya dalam mata pelajaran biologi.

Mata pelajaran biologi merupakan mata pelajaran yang termasuk dalam rumpun ilmu pengetahuan alam (IPA atau sains). Ilmu sainsberkaitan dengan cara mencari tahu (inquiry) tentang alam secara sistematis, sehingga pembelajaran bukan hanya sebagai penguasaan kumpulan pengetahuan yang berupa fakta-fakta, konsep-konsep atau prinsip-prinsip saja, tetapi juga merupakan suatu proses penemuan. Pembelajaran biologi di sekolah menengah diharapkan dapat menjadi wahana bagi peserta didik untuk mempelajari diri sendiri dan alam sekitar, serta prospek pengembangan lebih lanjut dalam kehidupan sehari-hari. Sehubungan dengan itu, pembelajaran biologi menekankan pada pemberian pengalaman secara langsung untuk mengembangkan kompetensi agar peserta didik menjelajahi dan memahami alam sekitar secara ilmiah.
Pembelajaran biologi diarahkan untuk mencari tahudan berbuat sehingga dapat membantu peserta didik untuk memperoleh pemahaman yang lebih mendalam tentang dirinya sendiri dan alam sekitar. Standar kompetensi dalam kurikulum pembelajaran biologi menyediakan berbagai pengalaman belajar untuk memahami konsep dan proses sains. Keterampilan proses ini meliputiketerampilanmengamati,

mengajukan hipotesis, menggunakan alat dan bahan secara baik dan benar dengan selalu mempertimbangkan keamanan dan keselamatan kerja, mengajukan suatu pertanyaan,menggolongkan dan menafsirkan suatu data, serta mengkomunikasikan hasil temuan secara lisan atau tertulis, menggali dan memilah informasi faktual yang relevan untuk menguji konsep/gagasan-gagasan atau memecahkan masalah sehari-hari. Bukan hanya guru menyampaikan materi dengan metode ceramah dan siswa hanya mendengarkan saja tanpa ada aktivitas yang menggugah siswa untuk berpikir dan aktif dalam pembelajaran. Oleh karena itu, perlu diterapkan model pembelajaran yang mengarahkan siswa untuk banyak beraktivitas dalam kegiatan pembelajaran.

Berdasarkan hasil pengalaman penulis sebagai guru biologi di Madrasah Aliyah Negeri (MAN) 4 Pidie, diperoleh data bahwa di Madrasah Aliyah Negeri 4 Pidie masih mengelami kendala-kendala dalam mempelajarai biologi diantaranya: pengajaran cenderung hanya menggunakan metode ceramah sehingga mengakibatakan komunikasi terjadi satu arah terfokus pada guru dan Peserta didik mengalami kesulitan karena pengajaran hanya ditekanakan pada hafalan-hafalan saja, hasil belajar yang belum tuntas yaitu masih banyak peserta didik yang mendapat nilai dibawah KKM yaitu 75 .

Selain itu, berdasarkan observasi awal penelitian mengenai materi struktur dan fungsi sel pada sistem reproduksi, peserta didik mengalami kesulitan memahami materi tersebut yang disebabkan metode pengajaran yang hanya menggunakan metode ceramah dan menghafalkan rumus- 
rumus yang ada tanpa menggunakan metode atau model bermain, sehingga mereka merasa bahwa pelajaran biologi merupakan mata pelajaran yang membosankan

Dari masalah yang dikemukakan di atas, perlu dicari strategi dan model pembelajaran baru yang dapat melibatkan siswa secara aktif. Pembelajaran yang mengutamakan kompetensi yang berpusat pada siswa, memberikan pembelajaran dan pengalaman belajar yang relevan dan kontekstual dalam kehidupan nyata dan mengembangkan mental yang kaya dan kuat pada diri siswa. Di sinilah guru dituntut untuk merancang kegiatan proses pembelajaran yang dapat mengembangkan dan meningkatkatkankompetensi, baik dalam ranah kognitif, ranah afektif, maupun psikomotorik siswa. Strategi pembelajaran yang berpusat pada siswa dan penciptaan suasana yang menyenangkan sangat diperlukan untuk meningkatkan hasil belajar siswa dalam mata pelajaran biologi. Dalam hal ini penulis memilih model pembelajaran yang menekankan pada adanya aktivitas dan interaksi di antara siswa untuk saling memotivasi dan saling membantu dalam menguasai materi pelajaran guna mencapai prestasi yang maksimal. Salah satunya dengan menerapkan cooperative learning dengan strategi bermain jawaban.

Strategi cooperative learning yang bisa dikembangkan pada pembelajaran biologi untuk meningkatkan keaktifan dan hasil belajar siswa salah satunya adalah bermain jawaban. Strategi ini adalah sebuah permainan yang dapat melibatkan semua peserta didik dari awal sampai akhir. Dalam permainan ini mereka ditantang untuk mencari jawaban yang benar dan sekaligus bergantung pada faktor keberuntungan. Permainan ini dapat digunakan untuk pretest maupun post-test, di samping tentunya untuk mengajarkan materi baru. Dalam permainan ini guru mengajar dengan menggunakan jawaban-jawaban yang ditemukan oleh peserta didik. Dari uraian di atas maka peneliti tertarik untuk mengadakan penelitian dengan judul "Penerapan Cooperative Learning dengan
Strategi Bermain Jawaban Dalam Meningkatkan Hasil Belajar Biologi Materi Struktur dan Fungsi Sel Pada Sistem Reproduksi di Kelas XI IPA.1 MAN 4 Pidie KabupatenPidie Tahun Pelajaran 2016/2017.

\section{KERANGKA TEORETIS}

\section{Definisi Pembelajaran}

Belajar pada prinsipnya adalah proses perubahan tingkah laku sebagai akibat dari interaksi antara peserta didik dengan sumber-sumber atau obyek belajar baik secara sengaja dirancang atau tanpa sengaja dirancang. Belajar ada kaitannya dengan usaha atau rekayasa pembelajar. Dari segi peserta didik, belajar yang dialaminya sesuai dengan pertumbuhan jasmani dan perkembangan mental, akan menghasilkan hasil belajar sebagai dampak pengiring, selanjutnya, dampak pengiring tersebut akan menghasilkan program belajar sendiri sebagai perwujudan emansipasi peserta didik menuju kemandirian.

Dari segi guru, kegiatan belajar peserta didik merupakan akibat dari tindakan pendidikan atau pembelajaran. Proses belajar peserta didik tersebut menghasilkan sikap perilaku yang dikehendaki, suatu hasil belajar sebagai dampak pengajaran. (Dimyati \& Mudjiono, 2002). Pasal 1 Undang-undang No. 20 tahun 2000 tentang pendidikan nasional menyebutkan bahwa pembelajaran adalah proses interaksi peserta didik dengan pendidik dan sumber belajar pada suatu lingkungan belajar.

Jadi pembelajaran adalah proses yang disengaja yang menyebabkan peserta didik belajar pada suatu lingkungan belajar untuk melakukan kegiatan pada situasi tertentu. Belajar dapat dilakukan di sembarang tempat, kondisi, dan waktu. Cepatnya informasi lewat radio, televisi, film, internet, surat kabar, majalah, dapat mempermudah belajar. Meskipun informasi dapat dengan mudah diperoleh, tidak dengan sendirinya seseorang terdorong untuk memperoleh pengetahuan, pengalaman, pengetahuan dan ketrampilan dari padanya.

2. Konsep Pembelajaran Biologi 
Biologi merupakan mata pelajaran yang termasuk dalam rumpun ilmu pengetahuan alam (IPA atau sains). Ilmu sainsberkaitan dengan cara mencari tahu (inquiry) tentang alam secara sistematis, sehingga pembelajaran bukan hanya sebagai penguasaan kumpulan pengetahuan yang berupa fakta-fakta, konsep-konsep atau prinsip-prinsip saja, tetapi juga merupakan suatu proses penemuan. Pembelajaran biologi di sekolah menengah diharapkan dapat menjadi wahana bagi peserta didik untuk mempelajari diri sendiri dan alam sekitar, serta prospek pengembangan lebih lanjut dalam kehidupan sehari-hari.

Dalamhubungannyadengan

pendidikan karakter bangsa, mata pelajaran biologi sebelumnya telah ditetapkan oleh standar nasional pendidikan (Depdiknas, 2008) sebagai mata pelajaran yang bertujuan sebagai berikut: (1) membentuk sikap positif terhadap biologi dengan menyadari keteraturan, keindahan alam, serta mengagungkan kebesaran Tuhan Yang Maha Esa; (2) memupuk sikap ilmiah yaitu jujur, objektif, terbuka, ulet, kritis dan dapat bekerjasama dengan orang lain; mengembangkan pengalaman untuk dapat mengajukan dan menguji hipotesis melalui percobaan, serta mengkomunikasikan hasil percobaan secara lisan dan tertulis; (4) mengembangkan kemampuan berpikir analitis, induktif, dan deduktif dengan menggunakan konsep dan prinsip biologi; (5) mengembangkan penguasaan konsep dan prinsip biologi dan saling keterkaitannya dengan IPA lainnya serta mengembangkan konsep pengetahuan, keterampilan dan sikap percaya diri; (6) menerapkan konsep dan prinsip biologi untuk menghasilkan karya teknologi sederhana yang berkaitan dengan kebutuhan umat manusia; dan (7) meningkatkan kesadaran dan berperan serta dalam menjaga kelestarian lingkungan.

Dengan tujuan di atas pemberian mata pelajaran biologi dimaksudkan untuk memperoleh kompetensi lanjut ilmu pengetahuan dan teknologi serta membudayakan berpikir ilmiah secara kritis, kreatif dan mandiri bagi peserta didik.

\section{Pengertian Cooperative Learning}

Dengan Strategi Bermain Jawaban

Suatu cooperative mengandung pengertian bekerja sama dalam mencapai tujuan bersama. Dalam kegiatan kooperatif, siswa secara individual mencari prestasi yang menguntungkan bagi seluruh anggota kelompoknya. Jadi, belajar kooperatif adalah pemanfaatan kelompok kecil dalam pengajaran yang memungkinkan siswa bekerja bersama untuk memaksimalkan belajar mereka dan belajar anggota lainnya dalam kelompok tersebut. Sehubungan dengan pengertian tersebut, Slavin (1984) mengatakan bahwa cooperative learning adalah suatu model pembelajaran dimana siswa belajar dan bekerja dalam kelompokkelompok kecil secara kolaboratif yang anggotanya terdiri dari 4 sampai 6 orang, dengan struktur kelompoknya yang bersifat heterogen.

Selanjutnya dikatakan pula, keberprestasian belajar dari kelompok tergantung pada kemampuan dan aktivitas anggota kelompok, baik secara individual maupun secara kelompok Pembelajaran kooperatif adalah konsep yang lebih luas meliputi semua jenis kerja kelompok termasuk bentuk-bentuk yang lebih dipimpin oleh guru atau diarahkan oleh guru. Secara umum pembelajaran kooperatif dianggap lebih diarahkan oleh guru, dimana guru menetapkan tugas dan pertanyaanpertanyaan serta menyediakan bahan-bahan dan informasi yang dirancang untuk membantu peserta didik menyelesaikan masalah yang dimaksud. Guru biasanya menetapkan bentuk ujian pada akhir tugas. Berdasarkan pengertian di atas dapat dikemukakan bahwa kelompok itu dapat terdiri dari dua orang saja, tetapi juga dapat terdiri dari banyak orang. Chaplin sebagaimana dikutip oleh Agus juga mengemukakan bahwa anggota kelompok tidak harus berinteraksi secara langsung yaitu face to face. Pada dasarnya cooperative learning mengandung pengertian sebagai suatu sikap atau perilaku bersama dalam bekerja atau membantu diantara sesama dalam struktur kerja sama 
yang teratur dalam kelompok, yang terdiri dari dua orang atau lebih dimana keberprestasian kerja sangat dipengaruhi oleh keterlibatan dari setiap anggota kelompok itu sendiri. Cooperative learning juga dapat diartikan sebagai suatu struktur tugas bersama dalam suasana kebersamaan diantara sesama anggota kelompok. Ada banyak strategi yang dikembangkan dalam cooperative learning salah satunya yaitu strategi bermain jawaban. Strategi bermain jawaban adalah teknik pembelajaran kelompok dimana setiap siswa saling memberikan pertanyaan dan jawaban.

Jadi cooperative learning dengan strategi bermain jawaban adalah proses belajar kelompok dengan teknik mengarahkan saling memberi pertanyaan dan jawaban.

\section{METODE PENELITIAN}

Pendekatan dalam penelitian ini menggunakan pendekatan kualitatif dengan menggunakan jenis penelitian tindakan kelas. Penelitian ini di lakuakan di MAN 4 Pidie Kabupaten Pidie Provinsi Aceh. Penelitian ini di lakukan dari bulan Februari sampai dengan bulan Mei 2017. Subjek Penelitin Subjek penelitian adalah siswa Kelas XI IPA.1 yang berjumlah 31 siswa. Data dalam penelitian ini diperoleh dari guru dan siswa. Variabel penelitian: (1) Keterampilan guru, (2) Aktivitas siswa, (3) Hasil belajar siswa. Teknik pengumpulan data yang digunakan adalah observasi untuk mengamati berlangsungnya proses pembelajaran, tes hasil belajar siswa, dan angket respon siswa digunakan untuk melihat respon siswa setelah diajarkan dengan menggunakan cooperative learning dengan strategi bermain jawaban.

\section{PEMBAHASAN HASIL PENELITIAN}

Berdasarkan hasil yang diperoleh dari pelaksanaan siklus I dan II, maka dapat dikatakan bahwa terjadi peningkatan hasil belajar siswa pada konsep adaptasi makhluk hidup. Hal ini dapat kita lihat dari hasil belajar siswa, aktivitas siswa pada saat PBM berlangsung dan kemampuan guru dalam melaksanakan PBM. Setelah dilakukan analisis peningkatan ini berkaitan langsung dengan penerapanmodel pembelajaran examples non examples.Aspekyang terpenting adalah peningkatan hasil belajar siswa. Selain dapat meningkatkan hasil belajar siswa dengan adanya cooperative learning dengan strategi bermain jawaban dapat juga berfungsi meningkatkan kemampuan daya pikir siswa pada konsep struktur dan fungsi sel pada sistem reproduksi yang selama ini dianggap sebagai materi yang sarat hafalan.

Hasil belajar siswa yang diperolehpada siklus I belum sesuai dengan harapan yang diinginkan yaitu $70 \%$. Hasil belajar siklus I hanya $61 \%$ siswa tuntas dan sebanyak 19 orang siswa yang memperoleh nilai lebih besar atau sama dengan 75 sesuai dengan nilai KKM. Mendapatkan hasil belajar yang belum sesuai dengan harapan yang diinginkan, maka tindakan dilanjutkan dengan siklus II untuk memperbaiki dan menyempurnakan hal - hal atau aspek yang masih kurang maksimal pada siklus I. Setelah dilakukan siklus II, ternyata terjadi peningkatan jumlah siswa yang memperoleh nilai lebih 75 yaitu sebanyak 26 orang dari jumlah total siswa 31 orang dengan persentase ketuntasan siswa $84 \%$. Jumlah ini jelas menunjukkan bahwa telah terjadi peningkatan yang cukup signifikan dari siklus I ke siklus II dan hasil tersebuttelah sesuai dengan yang diharapkan yaitu ketuntasan hasil belajar siswa sebesar $70 \%$. Data hasil belajar siswa antar siklus dapat dilihat pada tabel dibawah ini:

Tabel 4.9 Data hasil belajar siswa antar siklus

\begin{tabular}{|l|c|c|c|c|}
\hline \multirow{2}{*}{ Kegiatan } & \multicolumn{2}{|c|}{$\begin{array}{l}\text { Perolehan hasil } \\
\text { belajar (KKM 75) }\end{array}$} & \multicolumn{2}{|c|}{$\begin{array}{c}\text { Ketuntasan } \\
(\%)\end{array}$} \\
\cline { 2 - 5 } & $\begin{array}{l}\text { Nilai } \geq \\
75\end{array}$ & Nilai< & Tuntas & $\begin{array}{l}\text { Tidak } \\
\text { Tuntas }\end{array}$ \\
\hline Siklus I & 19 & 12 & $61 \%$ & $39 \%$ \\
\hline Siklus II & 26 & 5 & $84 \%$ & $16 \%$ \\
\hline
\end{tabular}

Observasi yang dilakukan terhadap aktifitas siswa pada siklus I sebanyak $64 \%$ siswa aktif dalam kegiatan PBM. Angka persentase keaktifansiswa yang diperoleh 
belum maksimal karena dari hasil observasi masih ada siswa yang tidak bekerja dalam kelompoknya serta kegiatandiskusi kelompok siswa dan diskusi kelas yang masih kurang. Hal ini disebabkan karena kurangnya bimbingan guru dalam melaksanakan kegiatan tersebut. Setelah dilakukan perbaikan dalam PBM pada siklus II terjadi peningkatan aktivitas siswa menjadi 71,86\%, Data aktivitas siswa antar siklus dapat dilihat pada tabel dibawah ini :

Tabel 4.10 : Data aktivitas siswa antar siklus

\begin{tabular}{|c|c|c|c|c|c|}
\hline \multirow[b]{2}{*}{ No } & \multirow[b]{2}{*}{$\begin{array}{l}\text { Aspek yang } \\
\text { diamati }\end{array}$} & \multicolumn{2}{|c|}{ Siklus I } & \multicolumn{2}{|c|}{ Siklus II } \\
\hline & & $\begin{array}{c}\text { Jumla } \\
\text { h } \\
\text { siswa } \\
\text { aktif }\end{array}$ & $\begin{array}{l}\text { Perse } \\
\text { ntase }\end{array}$ & $\begin{array}{c}\text { Jum } \\
\text { lah } \\
\text { sis } \\
\text { wa } \\
\text { akti } \\
\text { f }\end{array}$ & $\begin{array}{c}\text { Persen } \\
\text { tase }\end{array}$ \\
\hline 1 & $\begin{array}{l}\text { Memperhatikan } \\
\text { penjelasan guru }\end{array}$ & 27 & $87 \%$ & 29 & $93.5 \%$ \\
\hline 2 & $\begin{array}{l}\text { Bekerja dalam } \\
\text { kelompok }\end{array}$ & 24 & $77 \%$ & 29 & $93.5 \%$ \\
\hline 3 & $\begin{array}{l}\text { Mengajukan } \\
\text { pertanyaan pada } \\
\text { diskusi kelas }\end{array}$ & 22 & $71 \%$ & 24 & $77.4 \%$ \\
\hline 4 & $\begin{array}{l}\text { Menjawab } \\
\text { pertanyaan pada } \\
\text { diskusi kelas }\end{array}$ & 20 & $64 \%$ & 25 & $\begin{array}{c}80.6 \\
\%\end{array}$ \\
\hline 5 & $\begin{array}{l}\text { Memperbaiki } \\
\text { jawaban yang salah }\end{array}$ & 15 & $48 \%$ & 20 & $\begin{array}{c}64.5 \\
\%\end{array}$ \\
\hline 6 & $\begin{array}{l}\text { Tidak terlibat } \\
\text { dalam diskusi } \\
\text { kelompok }\end{array}$ & 10 & $32 \%$ & 4 & $\begin{array}{c}12.9 \\
\%\end{array}$ \\
\hline 7 & $\begin{array}{l}\text { Ikut merangkum } \\
\text { materi pelajaran }\end{array}$ & 21 & $68 \%$ & 25 & $\begin{array}{c}80.6 \\
\%\end{array}$ \\
\hline & $\begin{array}{l}\text { Rata-rata siswa aktif } \\
(\%)\end{array}$ & & $64 \%$ & & $71.86 \%$ \\
\hline
\end{tabular}

Persentase kemampuan guru dalam melaksanakan PBM pada antar siklus juga terjadi peningkatan. Kemampuan guru dalam mengelola PBM sebesar pada siklus I sebesar 80,6 \% dengan kategori baik dan pada siklus II meningkat menjadi $89 \%$ dengan kategori amat baik. Peningkatan ini terjadi karena perbaikan tindakan yang dilakukan pada siklus II terhadap kekurangan PBM yang dilaksanakan pada siklus I. Data Kemampuan guru pada saat melaksanakan PBM antar siklus dapat dilihat pada tabel dibawah ini

Tabel 4.11: Data Kemampuan PBM guru antar Siklus

\begin{tabular}{|l|l|l|l|}
\hline No & Aspek yang diamati & Siklu & Siklu \\
\hline
\end{tabular}

\begin{tabular}{|c|c|c|c|}
\hline & & Skor & Skor \\
\hline 1 & $\begin{array}{l}\text { Guru menyampaikan } \\
\text { tujuan pembelajaran }\end{array}$ & 3 & 4 \\
\hline 2 & $\begin{array}{l}\text { Guru memotivasi siswa } \\
\text { untuk mengikuti pelajaran } \\
\text { dengan baik }\end{array}$ & 3 & 3 \\
\hline 3 & $\begin{array}{l}\text { Guru mengelola PBM } \\
\text { dengan menggunakan } \\
\text { media } \\
\text { Media Gambar }\end{array}$ & 3 & 3 \\
\hline 4 & $\begin{array}{l}\text { Guru membimbing siswa } \\
\text { dalam diskusi kelompok } \\
\text { siswa }\end{array}$ & 4 & 4 \\
\hline 5 & $\begin{array}{l}\text { Guru membimbing siswa } \\
\text { dalam diskusi kelas }\end{array}$ & 3 & 4 \\
\hline 6 & $\begin{array}{l}\text { Guru membimbing siswa } \\
\text { dalam membuat } \\
\text { kesimpulan }\end{array}$ & 3 & 3 \\
\hline 7 & $\begin{array}{l}\text { Guru memberikan } \\
\text { penjelasan akhir terhadap } \\
\text { materi untuk penguatan } \\
\text { bagi siswa }\end{array}$ & 4 & 4 \\
\hline 8 & Pengelolaan waktu & 2 & 3 \\
\hline 9 & $\begin{array}{l}\text { Guru melakukan } \\
\text { penilaian }\end{array}$ & 4 & 4 \\
\hline \multicolumn{2}{|c|}{ Jumlah } & 29 & 32 \\
\hline \multicolumn{2}{|c|}{ Rata-rata skor (\%) } & $80.6 \%$ & $89 \%$ \\
\hline \multicolumn{2}{|c|}{ Kategori } & $\mathrm{B}$ & $\begin{array}{l}\text { Amat } \\
\text { Baik }\end{array}$ \\
\hline
\end{tabular}

Berdasarkan dari seluruh hasil tindakan

yang menunjukkanterjadinyapeningkatan hasil belajar siswa, peningkatan keaktifan siswa serta peningkatan terhadap kemampuan guru dalam melaksanakan proses belajar mengajar maka dapat disimpulkan bahwa penerapan pembelajaran kooperatif cooperative learning dengan strategi bermain jawabandapat digunakan pada pada konsep struktur dan fungsi sel pada sistem reproduksi.

\section{SIMPULAN DAN SARAN}

Berdasarkan hasil penelitian ini dapat disimpulkan bahwa : (1) bahwa penggunaan cooperative learning dengan strategi bermain jawaban dapat meningkatkan hasil belajar siswa pada konsep struktur dan 
fungsi sel pada sistem reproduksi di Kelas XI IPA.1 MAN 4 Pidie, diaman pada siklus I, siswa yang memperoleh nilai tuntas KKM 75 sebanyak 19 siswa dengan persentase $61 \%$ dan meningkat pada siklus II menjadi 26 orang dengan persentase $84 \%$; (2) penggunaan cooperative learning dengan strategi bermain jawaban dapat meningkatkan aktivitas siswa pada konsep struktur danfungsi sel pada sistem reproduksi di Kelas XI IPA.1 MAN 4 Pidie, dimana aktifitas siswa pada siklus I sebanyak $64 \%$ siswa aktif dalam kegiatan PBM dan setelah dilakukan perbaikan dalam PBM pada siklus II terjadi peningkatan aktivitas siswa menjadi 71,86; (3) penerapan cooperative learning dengan strategi bermain jawaban dapat meningkatkan kemampuan guru dalam mengelola proses pembelajaran pada konsep struktur dan fungsi sel pada sistem reproduksi di Kelas XI IPA.1 MAN 4 Pidie, dimana persentase kemampuan guru dalam melaksanakan PBM pada siklus I sebesar 80,6 \% dengan kategori baik dan pada siklus II meningkat menjadi $89 \%$ dengan kategori amat baik

Berdasarkan kesimpulan dan kondisi selama dilakukannya penelitian, maka peneliti dapat memberikan saran-saran sebagai berikut: (1) kepada guru-guru IPA khususnya biologi yang sering menemukan kendala dalam penyampaian materi kepada siswa agar dapat merancang proses pembelajaran yang sesuai dengan materi yang ingin disampaikan sehingga materi tersebut dapat diterimadengan baik oleh siswa. Terutama pada pemanfaatan media pembelajaran yang merupakan salah satu alat bantu dalam kegiatan Proses belajar mengajar; (2) khusus untuk penyampaian konsep struktur dan fungsi sel pada sistem reproduksi dapat dilakukan dengan penerapan cooperative learning dengan strategi bermain jawaban agar proses pembelajaran menjadi lebih menarik dan menyenangkan bagi siswa.; dan (3) bagi guru yang tertarik dengan penelitian ini disarankan untuk menerapkan model pembelajaran lain pada konsep struktur dan fungsi sel pada sistem reproduksi untuk variasi dalam dunia pendidikan kita.

\section{DAFTAR PUSTAKA}

Asnawir dan Basyiruddin, 2002, Media Pembalajaran, Jakarta, Ciputat Perss

Azhar, Arsyad, 2007, Media Pembelajaran, Jakarta, Raja Grafindo Persada

Depdiknas. 2004. Materi Pelatihan Terintegrasi-Matematika. Jakarta: Dirjen Dikdasmen.

Ibrahim, M, dkk. 2000. Pembelajaran Kooperatif. Surabaya: University Press.

Lie, Anita. 2004. Cooperative Learning Mempraktikkan Cooprerative Learning di Ruang-Ruang Kelas. Jakarta: Grasindo.

Sanjaya. 2008. Kurikulum dan Pembelajaran, Jakarta: Kencana

Sadiman, Arief, dkk, 2002, Media Pendidikan:Pengertian, Pengembangan dan Pemanfaatannya, Jakarta, Raja Grafindo Persada

Slavin, Robert E. Cooperative Learning, Massacusetts: Allyn \&Bacon, 1995

Slameto, 1995, Belajar dan Faktor-Faktor yang Mempengaruhinya, Jakarta, Rineka Cipta

Solihatin, Etin, 2007, Cooperative Learning, Jakarta: Rineka Cipta

Solihatin, Etin,2008. Cooperative Learning Analisis Model Pembelajaran IPS, Jakarta: Bumi Aksara

Sudjana, 2005, Penilaian Hasil Proses Belajar Mengajar, Bandung, Remaja Rosdakarya 
Sukmadinata, Ibrahim, 2001. Pembelajaran Kooperatif, Surabaya: Universitas Negeri Malang
Zaini, Hisyam, dkk,2008. Strategi Pembelajaran Aktif, Yogyakarta: Pustaka Insan Madani. 